\title{
PSYCHE
}

VOL. XXV1

APRIL, 1919

No. 2

\section{A LIST OF THE ORTHOPTERA OF NEW ENGLAND.}

\author{
By Albert P. Morse, \\ Wellesley College, Wellesley, Mass.
}

Eighteen years ago Mr. S. H. Scudder published in this journal a briefly annotated list of the Orthoptera of New England (Psyche, Vol. 9, September, 1900, pp. 99-106) enumerating 98 species, and on page 119 following added six more from data supplied by Mr. Samuel Henshaw.

Since that date much work has been done upon the group, greatly increasing the number of species known from New England and changing their scientific nomenclature. In a Manual of the New England Orthoptera soon to be published I have enumerated 130 species from the district. The following list is intended to serve as a short memorandum of these.

Order DERMAPTERA,-Earwigs.

1. Maritime Earwig, Anisolabis maritima Géné.

Nearly cosmopolitan. Introduced and established at various points on our seabord, living as a scavenger among the shingle and sea-wrack at or near highwater mark. Hibernates as an adult. Eggs laid in summer. Reported from Maine, Massachusetts, Rhode Island, and Connecticut.

2. Ring-legged Earwig, Euborellia annulipes Lucas.

Introduced. Taken in slaughter-house at Brighton, Mass., Feb. 1909 (A. P. M.), and by Walden among shipments of plants in Connecticut.

3. Little Earwig, Labia minor Linné.

Generally distributed and probably occurs in small numbers throughout New England. Has been captured from May 25 to Nov. 4 under various circumstances, in gardens, manure-heaps, and fungi. Nocturnal, flying at dusk, and to lights in evening. 
4. Brown Earwig, Prolabia arachidis Yersin.

Introduced. Taken in sugar refinery at Boston in 1889 (Henshaw) and in Brighton slaughter-house, Feb. 1909 (A. P. M.). In New England occurs only under artificial conditions.

5. European Earwig, Forficula auricularia Linné.

Introduced from Europe. Established at Newport, R. I., and vicinity. Has been taken also at Kingston, R. I., and in browntail moth nests imported with parasites at Melrose, Mass.

6. Spandex percheron Guerin et Percheron.

One example of this species (t. Hebard, Notes, Entom. news, xxviii, 323, 1917) is recorded from New England. The record is based on a badly mutilated specimen in the Harris collection, taken in Boston or vicinity, which was described as new by Scudder under the name of Spongophora bipunctata (Boston journ. nat. hist., vii, 415, 1862).

Order ORTHOPTERA, Family Blattid

Native Species (Ischnoptera auct.).

7. Common, or Northern, Wood-Roach, Parcoblatta virginica Brunner.

Common under bark, boards, stones, etc., in June and July, less so in August. Males fly freely to light; females are wingless. Orono, Me., Hartland, Vt., and southward.

8. Uhler's Wood-Roach, Parcoblatta uhleriana Saussure.

Much less common than the preceding but frequently seen in eastern Massachusetts and recorded from Marthas Vineyard and Connecticut. Habits and seasons same as preceding.

9. Pennsylvanian Wood-Roach, Parcoblatta pensylvanica DeGeer.

Scarce or rare in eastern New England, locally plentiful on shore of Lake Champlain. Found under boards and stones from June 5 to October. Recorded from Prout's Neck, Maine, Sherborn and Winthrop, Mass., Mt. Carmel, Ct., South Hero, Vt.

10. Broad Wood-Roach, Parcoblatta lata Brunner.

Adventive from further south. One example taken at Wellesley, Mass., July 13, 1916, in dwelling-house (A. P. M.). 
Introduced Species which have established themselves for longer or shorter periods.

11. German Roach, Croton-bug, Blattella germanica Linné.

Domiciliary. Probably occurs throughout New England under artificial conditions of constant heat, moisture, and food, in houses, shops, etc. Adults and young at all seasons. Locally abundant if not checked.

12. Oriental Roach, Blatta orientalis Linné.

Much less common than the preceding; found under the same conditions.

13. American Roach, Periplaneta americana Linné.

Locally plentiful under the same conditions as the preceding but less generally established. Our largest common roach.

14. Australian Roach, Periplaneta australasia Fabricius.

Occasionally becomes established in greenhouses, etc. Taken in Maine, Massachusetts, and Connecticut.

15. Surinam Roach, Pycnoscelus surinamensis Linné.

Remarks under preceding apply equally well to this. Recorded from Massachusetts and Connecticut.

Exotic species from West Indies, Central or South America, introduced with tropical fruit; adventive, liable to occur at any time or in any place where such merchandise is unpacked.

16. Nyctibora lavigata Beauvois ("sericea" of authors).

Female, Orono, Me., May 16, 1889, bananas (Me. exp. sta.). Female, Manchester, N. H. (Miss Susy C. Fogg). Male, Boston, Mass., Feb. 20, 1887 (F. H. Sprague). Natick, Mass., summer, 1901, fruit store (A. P. M.). Female, Springfield, Mass., Aug. 17, 1898 (C. Ladd). Wellesley, Mass., fall, 1899,--nymph, re_ corded by Scudder (List, Psyche 1900, 100) as "Eurycotis, pos_ sibly finschiana Sauss."

17. Nyctibora noctivaga Rehn ("holosericea").

Wellesley, Mass., Jan. 15, 1904, bananas; adult. Young in various stages: Dalton, Mass., Jan. 2, 1899 (E. A. Halle). Hyde Park, Mass., Oct. 1, in house (Miss M. E. Cherrington). Fram- 
ingham, Mass., May 25, in store (C. A. Frost). Newtonville, Mass., June 12, 1916 (A. W. Wilcox).

18. Eurycotis opaca Brunner.

Female, Orono, Me., June 18, 1909 (Me. exp. sta.).

19. Eurycotis tibialis Hebard.

Female, Orono, Me. ? (Me. exp. sta.).

20. Epilampra maya Rehn.

Female, Woodstock, Vt., August, 1911 (Hugh Morgan). Female, Framingham, Mass., April 10, 1914, bananas in grocery store (C. A. Frost).

21. Green Roach, Panchlora cubensis Saussure.

Female, Augusta, Me., 1906 (U. S. N. M.). Orono, Me., 1892, in tropical fruit (Me. exp. sta.). Woodstock, Vt. (A. P. M.). Boston, Mass., Dec. 26, 1878, flying in store (M. C. Z.); Framingham, Mass., Aug. 1, 1914 (C. A. Frost); Melrose, Mass., June 17, 1914 (F. W. Dodge); Salem, Mass., Aug. 1, 1890, Aug. 12, 1917; Stoneham, Mass., Nov. 15, 1915 (C. V. Blackburn); Wellesley, Mass., Dec. 12, 1894, on window; Jan. 9, 1918, bananas (A. P. M.).

22. Green Roach, Panchlora exoleta Burmeister.

Salem, Mass., June 7, 1884, probably in bananas (Peabody Museum).

23. Hormetica advena Scudder.

One female, Belmont, Mass. (type). Native country unknown. Family Phasmide, Walkingsticks.

24. Northern Walkingstick, Diapheromera femorata Say.

Not uncommon locally, usually in deciduous shrubbery, in southern New England. Known from South Bridgton, Me. (Me. exp. sta.), Manchester, N. H., and Sudbury, Vt., southward, from late August till October.

25. Blatchley's Walkingstick, Manomera blatchleyi Caudell.

One adult female, one immature, Greenwich, Ct., Aug. 25, 1892 (A. P. M.). 
Family Mantidae, Praying Mantids.

26. Carolina Mantis, Stagmomantis carolina Johannsen.

Reported by Mr. Samuel Henshaw from Rhode Island, many years ago, through Prof. Packard. Probably adventive or introduced, as it does not naturally live within a long distance of our border.

27. Chinese Mantis, Paratenodera sinensis Saussure.

Introduced several times into Connecticut and Massachusetts but has not established itself.

28. European Praying Mantis, Mantis religiosa Linné.

Introduction of this species into Connecticut by egg-masses from the colony at Rochester, N. Y., was once attempted but they failed to hatch.

Family Tetrigonidd,--Katydids, Green Grasshoppers, Cavecrickets, etc.

29. Oblong-winged Katydid, Amblycorypha oblongifolia DeGeer.

Common in vines, shrubbery, and coarse weeds in Connecticut, less numerous in eastern Massachusetts, and recorded from southern New Hampshire. Mid-August to October.

30. Carinate Florida Katydid, Amblycorypha floridana carinata Rehn et Hebard.

Half-a-dozen examples are recorded from Nantucket and Woods Hole, Mass., and it will probably be found in Connecticut. Frequents bushes and weeds.

31. Round-winged Katydid, Amblycorypha rotundifolia rotundifolia Scudder.

Common in southern New England in grass and low bushes in August and September. It is reported from as far north as the White Mountain region.

32. Northern Bush-Katydid, Scudderia septentrionalis Serville.

Very rare. Has been taken in Maine and eastern Massachusetts in July and August on undergrowth in woods.

33. Texan Bush-Katydid, Scudderia texensis Saussure et Pictet.

Common in swampy ground from July till October. Recorded 
from Norway, Me., Seabrook, N. H., eastern Massachusetts, and throughout Connecticut.

34. Broad-winged Bush-Katydid, Scudderia pistillata Brunner.

A boreal species common in low shrubbery throughout New England. July till September.

35. Curve-tailed Bush-Katydid; Scudderia curvicauda curvicauda DeGeer.

Very common in shrubbery in southern New England and extending northward to middle Vermont and southwestern Maine (Fryeburg). July to September.

35a. Northern Curve-tailed Bush-Katydid, Scudderia curvicauda borealis $\mathbf{R}$. et $\mathbf{H}$.

A northern race of the preceding, a few examples of which $I$ have taken in eastern Maine in cold heath-grown bogs, in August.

36. Fork-tailed Bush-Katydid, Scudderia furcata furcata Brunner.

Very common in tall grasses, bushes, and shrubbery, from July till October, from southern Maine and New Hampshire southward.

37. European Short-winged Bush-Katydid, Leptophyes punctatissima Bosc d'Antic.

Three examples of this species have been captured on Nantucket. It was doubtless introduced with commercial importations of plant materials but whether it still survives is unknown.

38. The Katydid, True Katydid, Pterophylla camellifolia Fabricius.

Arboreal, frequenting oak trees especially. Common locally in Connecticut and warmer parts of Massachusetts in September and October.

39. The Sword-bearer, Neoconocephalus ensiger Harris .

Our commonest cone-head, known from Norway, Me., southward. Late July till September. In grasslands, wild and cultivated.

40. Robust Cone-head, Neoconocephalus robustus robustus Scudder.

Common coastwise from Cape Cod southward, in sand-grass, and cat-tail marshes. August and September. 
41. Round-tipped Cone-head, Neoconocephalus retusus Scudder.

Common, locally at least, in southern Connecticut in tall grass in meadows. August to October.

42. Unmusical Cone-head, Neoconocephalus exiliscanorus Davis.

One example is recorded by Walden from New Haven, Ct. It is said to be locally common in the vicinity of New York from August onward.

43. Broad-tipped Cone-head, Neoconocephalus triops Linné.

Two adventive examples of this southern species have been taken in Massachusetts in houses in winter, introduced with spinach greens from the south.

44. Larger Meadow-Grasshopper, Orchelimum vulgare Harris.

Very common in southern New England and probably occurring throughout. Prefers tall grasses and dense weedy jungles on moist or wet ground. July till October.

45. Bruner's Meadow-Grasshopper, Orchelimum gladiator Bruner.

In the same haunts as the preceding but less common in southern New England.

46. Dusky-faced Meadow-Grasshopper, Orchelimum concinnum Scudder.

Locally common in the coarse vegetation of tidal runways of coastwise saltmarshes in southern New England. Recorded from Rye Beach, N. H., vicinity of Boston, and Connecticut, from July 22 to Sept. 6.

47. Slender Meadow-Grasshopper, Conocephalus fasciatus fasciatus DeGeer.

Abundant in damp grasslands throughout New England from late July till October.

48. Short-winged Meadow-Grasshopper, Conocephalus brevipennis Scudder.

Very common in weedy jungles and dense grass in most of New England from late July till hard frost. Recorded from Eastport, Me., and Jefferson, N. H., southward. 
49. Saltmarsh Meadow-Grasshopper, Conocephalus spartino Fox.

Locally abundant in short grasses of coastwise saltmarshes. Known from Old Orchard, Me., southward.

50. Wingless Prairie Grasshopper, Conocephalus saltans Scudder.

Common among low shrubs and tufts of bunch-grass on the sandy moors of Nantucket. August and September.

51. Long-legged Shield-bearer, Atlanticus americanus Saussure, and

52. Short-legged Shield-bearer, Atlanticus testaceus Scudder.

Scarce. Our two Shield-backed Grasshoppers live in dry woodlands, bushy pastures, etc., where they may be found crawling slowly over the dead leaves, or perhaps stridulating from some bush. Adults are recorded from the vicinity of Boston, Cape Cod, Marthas Vineyard, Connecticut, and Sudbury, Vt., from late July till October. A third species possibly occurs in western New England.

53. Asiatic or Greenhouse Cave-cricket, Diestrammena marmorata DeHaan.

Introduced into greenhouses and cellars in several parts of New England. It multiplies rapidly and quickly becomes abundant. I have received examples from Kennebunk, Me., Danvers and Springfield, Mass. Adults and young throughout the year.

Native Cave-crickets, Ceuthophilus spp.

Our native cave-crickets, stone-crickets, or camel-crickets are usually found under bark, boards, stones, etc., or in cellars and holes during the day, emerging at night in search of food. Adults are most numerous out-of-doors in late summer and fall, but hibernating examples are not rare in favorable conditions. The genus needs thorough collecting in liquid preservative and complete revision.

54. Spotted Cave-cricket, Ceuthophilus maculatus Harris.

Our commonest camel-cricket, probably found throughout New England. Gregarious, under stones, logs, and in cellars.

55. Yellow Cave-cricket, Ceuthophilus neglectus Scudder. Probably throughout New England in woodlands. Recorded 
from Jackman, Me., Plymouth, Vt., eastern Massachusetts, and Connecticut.

56. Woodland Cave-cricket, Ceuthophilus neglectus Scudder.

A common species in cool, moist woodlands and forests in Vermont and New Hampshire.

57. Short-legged Cave-cricket, Ceuthophilus brevipes Scudder.

Rare. Recorded from Grand Manan, N. B., and North Madison, Ct.

58. Black-sided Cave-cricket, Ceuthophilus latens Scudder.

Walden has taken this species at Lyme, Ct., under stones, in August.

59. Pale-footed Cave-cricket, Ceuthophilus lapidicola Burmeister.

$$
\text { (C. pallidipes E. M. Walker.) }
$$

Not common. Reported from New Haven, Ct., and Wellesley, Mass.

60. Slender-legged Cave-cricket, Ceuthophilus gracilipes Haldeman.

Captured in cellars and under bark of fallen trees in Connecticut by Walden in August and September. Half-grown young in cave at New Ashford, Mass., Dec. 22, (G. M. Allen). An example of the variety stygius Scudder has been taken at Beverly, Mass.

Family Gryluid e, Crickets, Tree-crickets, Mole-crickets.

61. Common Field-cricket, Gryllus assimilis Fabricius.

Very common throughout New England especially in sandy areas. June till heavy frost. In southern New England a few nymphs hibernate.

62. Striped Grass-cricket, Nemobius fasciatus fasciatus DeGeer.

Abundant everywhere, probably throughout New England, in grasslands. July till late fall.

63. Sand Cricket, Nemobius griseus E. M. Walker.

Known in small numbers from sandy districts in Maine, Massachusetts, and Connecticut. August and September. 
64. Little Spotted Cricket, Nemobius maculatus Blatchley.

New Canaan, Ct., Sept. 11, B. H. Walden. Extra-limitally it is said to live in low open woods in damp places.

65. Sphagnum Cricket, Nemobius palustris Blatchley.

Locally common in sphagnum-bogs at Orono, Me., in eastern Massachusetts and Connecticut. September and October.

66. Cuban Ground-cricket, Nemobius cubensis Saussure.

Doubtfully present in small numbers in Connecticut. A few specimens have been taken which seem to intergrade with the preceding.

67. Carolina Ground-cricket, Nemobius carolinus Scudder.

Locally common throughout New England. Damp soils, edges of woodlands, stream-sides, etc. August to November.

68. Snowy Tree-cricket, Oecanthus niveus DeGeer.

Recorded from vicinity of Portland, Me., and common throughout southern New England in shrubbery near houses, orchards, gardens, etc., from late August till October. Observation of its song should greatly extend its known range.

69. Narrow-winged Tree-cricket, Oecanthus augustipennis Fitch.

This species has been taken near Boston, Mass., and at various points in Connecticut between Aug. 14 and Oct. 20. It frequents orchards and fruit trees and even low thickets of sweetfern.

70. Davis's Tree-cricket, Oecanthus exclamationis Davis.

Recorded by Walden from trunks of trees, near New Haven, from August to October. On Long Island it is found on bur oak.

71. Four-spotted Tree-cricket, Oecanthus quadripunctatus Beutenmüller.

Widely distributed and locally abundant in southern New England, extending north as far at least as Woodstock, Vt., Hoxies and Brunswick, Me. Lives in weedy thickets of wild carrot, Joe-Pye-weed, raspberry bushes, etc. August till October.

72. Dusky Tree-cricket, Oecanthus nigricornis Walker.

Found in same places as last and nearly as common. Inhabits all the New England States. 
73. Pine Tree-cricket, Oecanthus pini Beutenmüller.

Said to live only in pine-trees. Reported from Gloucester, Cape Cod, and Marthas Vineyard, Mass.

74. Two-spotted Tree-cricket, Neoxabea bipunctata DeGeer.

Known in small numbers from Connecticut: New Canaan, New Haven, and Portland, Aug. 14 to Sept. 11.

75. Striped Bush-cricket, Anaxipha exigua Say.

Walden reports this species at Westbrook, Ct., living in tangled vegetation on and near saltmarshes.

76. Hapithus vagus Morse.

An adventive exotic species which maintained itself for several years in the greenhouses of the Botanic Garden at Cambridge, Mass.

77. American Mole-cricket, Gryllotalpa hexadactyla Perty.

Probably occurs throughout New England but is very local and difficult to capture. Lives in meadows, along streams and about ponds, burrowing in the turf and muddy shores. Its call might easily be mistaken for that of a small frog.

78. European Mole-cricket, Gryllotalpa vulgaris Latreille.

Reported from Nantucket, where it was doubtless introduced with importations of plants from Europe. Whether established or not remains to be proved.

79. Pygmy Mole-cricket, Tridactylus apicalis Say.

Lives on and in the damp sand on the edges of ponds and streams. Recorded from Connecticut, and from Cambridge, Winchester, and Nantucket, Mass. Adults were common at the last-named locality on July 13; a few nymphs were found on the same date and on Sept. 10.

Family ACRIDIDes, Locusts.

Subfamily Acridinæ (Tryxalinæ auct.).

80. Bunch-grass Locust, Pseudopomala brachyptera Scudder.

Common locally in coarse grasses, especially Andropogon scoparius, on wild and uncultivated lands from southwestern Maine, southern New Hampshire and Vermont southward, including Marthas Vineyard and all of Connecticut. July to September. 
81. Velvet-striped Locust, Eritettix simplex Scudder.

Rare. Walden records it from several points in southern Connecticut on light dry soil with but little vegetation, such as abandoned fields and dry pastures. Adults are recorded on Oct. 31 and from May 25 to June 30. They apparently hibernate.

82. Bicolored Locust, Dichromorpha viridis Scudder.

Common in southern New England (except southeastern Mass.) from late July onward, often locally abundant in Connecticut. Most plentiful in damp pastures and mowing-lands in dense succulent grass. It has decidedly increased in numbers in the vicinity of Boston within the last twenty-five years, apparently spreading northeastward.

83. Pasture Locust, Orphulella speciosa Scudder.

Found throughout the Transition and Austral areas of New England from Grand Lake Stream, Orono, and Norway, Me., southward, including Nantucket and Marthas Vineyard. Common locally, abundant southward. Generally distributed on dry soils. Adults appear early in July and are common until October.

84. Spotted-winged Locust, Orphulella pelidna Burmeister.

Widely distributed over southeastern third of New England on sandy soils. Abundant southward, especially coastwise, but unknown as yet from north of Massachusetts. Adults begin to appear a little later than the preceding species.

85. Saltmarsh Locust, Orphulella olivacea Morse.

Locally plentiful on saltmarshes on the Connecticut shore. Known from New Haven, Stratford, Stamford, and Greenwich, from August 11 to 28. Continued collecting coastwise will probably greatly extend dates of capture and New England distribution record.

86. Sprinkled Locust, Chloealtis conspersa Harris.

Locally common throughout New England from late June onward, particularly in July in bushy pastures and along the edges of woodlands. Eggs are laid in wood-stumps, boards, rails, etc.

87. Meadow Locust, Chorthippus curtipennis Harris.

Common, often abundant locally, throughout New England. In damp places, meadows, saltmarshes, brooksides, ditch borders, 
wherever there is a thick and succulent growth of herbage. Adults from early June till mid-November.

88. Striped Sedge Locust, Mecostethus lineatus Scudder.

Locally plentiful in cold wet sedge meadows and bogs, probably throughout New England, at all elevations from sea-level to the summit of Katahdin. Adults have been captured from July 21 to Oct. 6.

89. Northern Sedge Locust, Mecostethus gracilis Scudder.

In the same habitats as the preceding but restricted to the northern tier of States and high elevations in Massachusetts. Locally common, July 12 to Sept. 6 and probably later.

90. Broad-winged Sedge Locust, Mecostethus platypterus Scudder.

A rare species having the same haunts as lineatus, recorded as yet (in New England) only from Sherborn, Mass., and Thompson, Ct., in August. It probably inhabits at least the southern half of New England.

Subfamily CEdipodinæ, Band-winged Locusts.

91. Autumn Yellow-winged Locust, Arphia xanthoptera Burmeister.

Locally common in dry pastures from late July to November in the warmer parts of the Transition zone, from middle New Hampshire (Scudder) southward, including Nantucket and Marthas Vineyard.

92. Spring Yellow-winged Locust, Arphia sulphurea Fabricius.

Common and widely distributed in dry bushy pastures and wild land in spring and early summer, from May till August. It is probably found throughout New England, though as yet not recorded from north of Deering and Norway, Me., Berlin Falls and Hanover, N. H. The young are active on warm days in winter.

93. Green-striped Locust, Chortophaga viridifasciata DeGeer.

Generally distributed throughout New England in pastures and mowing-lands. Adults appear in mid-April and linger till frost, though most plentiful from May till July; rarely, freshly matured individuals are seen in the fall. The young are plentiful and often conspicuous in their haunts on warm days in winter. 
94. Dusky, or Clouded Locust, Encoptolophus sordidus Burmeister.

Common, often abundant, in weedy fields and pastures from late July till November. Inhabits the warmer parts of New England from Orono, Me., southward.

95. Clear-winged Locust, Camnula pellucida Scudder.

Dangerously abundant locally in dry fields and pastures throughout northern New England, maturing in June and active till late in the fall. It occurs in small numbers as far south as northeastern Massachusetts, northeastern and middle western Connecticut.

96. Coral-winged Locust, Pardalophora apiculata Harris.

Common throughout New England, especially in bushy pastures and wild land, from mid-April to July. Found from Nantucket to summit of Mt. Washington. The young hibernate and may frequently be found in mid-winter.

97. Wrinkled Locust, Hippiscus rugosus Scudder.

Recorded from Norway, Me., and eastern Massachusetts many years ago. No specimens have been taken in New England recently. It should be looked for in July and August on the sandy coastal plain.

98. Carolina Locust, Black-winged Locust, Dissosteira carolina Linné.

Very common throughout the Transition and Austral parts of New England on the bare soil of roads, gravel-pits, vacant lots, pastures, and sea-beaches, from early July till late in the fall.

99. Collared Locust, Scudder's Waste-Land Locust, Spharagemon collare scudderi Morse.

Common, even plentiful locally, in sandy districts in southern New England from Brunswick, Me., Ossipee and Manchester, N. H., and Vermont, southward to Nantucket, Marthas Vineyard and southern Connecticut. July till October.

100. Boll's Locust, Spharagemon bolli Scudder.

Generally distributed throughout the Transition and Austral areas of New England. Semi-sylvan, inhabiting bushy pastures on upland soil. July till October. 
101. Ledge Locust, Spharagemon saxatile Morse.

Common on exposed ledges in eastern Massachusetts and throughout Connecticut, from July till October.

102. Marbled Locust, Scirtetica marmorata Harris.

Locally common in sandy tracts in southern Connecticut, Marthas Vineyard, the Cape Cod district (Dennis, Provincetown), and has been taken at Manchester, N. H. (Fogg). July till October.

103. Sand Locust, Long-horned Locust, Psinidia fenestralis Serville.

Very common and widely distributed on wind-blown sand, along the coast, inland river-beaches, sand-pits, dune areas, etc. Recorded from Brunswick and Norridgewock, Me., No. Conway, N. H., Grand Isle, Vt., and many localities in Massachusetts, Rhode Island, and Connecticut. June till November.

104. Seaside Locust, Trimerotropis maritima Harris.

Very common on sandy sea-beaches and adjoining dune areas from Old Orchard, Me., southward. Has been taken inland only at North Haven, Ct. July till November.

105. Snapping Locust, Broad-winged Locust, Circotettix verruculatus Kirby.

A boreal species, very common in the Canadian zone and extending southward at least as far as Gloucester and Palmer, Mass., Colebrook and Canaan, Ct. It frequents exposed rocks and ledges, and to a less extent bare earth and roadsides as well. July till October.

Subfamily Locustinæ (Acridiinæ), Spine-breasted Locusts.

106. American Locust, Schistocerca serialis Drury.

Does not usually breed in New England, but stray individuals occasionally reach southwest Connecticut by flight. A colony was found at Wollaston, Mass., in 1883 by F. H. Sprague.

107. Rusty Locust, Leather-colored Locust, Schistocerca alutacea

Harris and

107a. Schistocerca alutacea rubiginosa Scudder.

Common locally from Manchester, N. H., southward in the coast-plain area of Massachusetts, Rhode Island, and Connecticut. 
The unstriped form (rubiginosa) is more usual in the north and on upland stations; the striped form (alutacea) along the southern coast and in grassy swamps. Adults have been taken from Aug. 5 till Oct. 30.

108. White Mountain Wingless Locust, Podisma glacialis glacialis Scudder.

A strictly boreal species, locally common from sea-level in eastern Maine to subalpine thickets on the highest mountains of New England. It is found in shrubby thickets in cold bogs, moist woodlands, and at timber-line on mountains. Adults from July till September. It is found on the summits of Greylock Mt., Mass., Ascutney Mt., Vt., Chocorua and Pequaket, N. H.; bogs at Umbagog Lake, Orono, Cherryfield, and Roque Bluff, Me.; and many other points north of these.

109. Swamp Locust, Paroxya clavuliger Serville.

Locally common in swamps and marshes (both salt and fresh) of southern New England from vicinity of Boston southward. July till October.

110. Purple-striped Locust, Hesperotettix brevipennis brevipennis Thomas.

Rare and local. Has as yet been taken at but three points in New England: Wellesley, Dover, and Walpole, Mass., in bunchgrass (Andropogon scoparius). July till September.

111. Lesser Migratory Locust, Melanoplus atlanis Riley.

Dangerously abundant throughout New England, sometimes doing severe injury locally. Most plentiful on sandy loam. June till November.

112. Yellow-striped Locust, Melanoplus bivittatus Say.

Common throughout New England from sea-coast to mountaintop, frequenting especially the rank vegetation of meadows and springy runs. Sometimes does much injury locally. June to November.

113. Red-legged Locust, Melanoplus femur-rubrum DeGeer.

Probably our most generally distributed and injurious "grasshopper," though sometimes outnumbered by atlanis. Prefers damper situations than atlanis. July to November. 
114. Northern Locust, Melanoplus borealis Fieber.

A boreal species common from northern Massachusetts northward. Frequents the dense grass of moist meadows, bogs, sedgy swamps and mountain-tops. June to September.

115. Little Locust, Melanoplus confusus Scudder.

Common in grassy fields and pastures on sandy loam, from June till August, probably throughout the Transition and Austral areas of New England. Known from Fryeburg, Me., Jackson, N. H., Woodstock, Vt., and southward.

116. Broad-necked Locust, Melanoplus luridus Dodge.

A common, widely distributed, semi-sylvan species, appearing in late July and active till the ground freezes. Bushy pastures, edges of forests, open woodlands. Probably occurs throughout New England.

117. Pine-tree Locust, Melanoplus punctulatus Scudder.

Scarce, almost rare, but sometimes common locally, usually associated with groves or trees of white pine, on which it lives. The eggs are laid in holes made by borers in the trunk or bark. Recorded from Brunswick, Me., No. Conway, N. H., Vermont, and southward. Late July to November.

118. Banded Locust, Huckleberry Locust, Melanoplus fasciatus Walker.

Widely distributed and common locally, often in huckleberry thickets on sterile soil, from the sandy moors of Cape Cod and Nantucket to the highest mountain summits. June till September.

119. Dawson's Locust, Melanoplus dawsoni Scudder.

Rare in New England; known only from Manchester, N. H., Brunswick, and one other locality in southwestern Maine, and in the coarse grasses of dry fields among pitch pines on gravelly soil. July to September.

120. Smith's Locust, Melanoplus mancus Smith.

Widely distributed but very local. Found from eastern Maine to southern Connecticut, frequenting dwarf blueberry thickets on dry mountain summits and hill-tops. Dates of capture range from Aug. 8 to Sept. 6; these will probably be much extended by further collecting. 
121. Scudder's Short-winged Locust, Melanoplus scudderi Uhler.

Locally common in southern New England in brushy thickets in August and September. It has been taken at Springfield and Wareham, Mass., and New Haven, Ct.

122. Green-legged Locust, Melanoplus viridipes Scudder.

Mr. C. W. Johnson has taken this species at five points along our western border: Bashbish Falls, Great Barrington, and Williamstown, Mass., Mansfield and St. Albans, Vt., all in June. It was found among low shrubby thickets on dry upland soil.

123. Large-headed Locust, Photaliotes nebrascensis Scudder.

Only one example is known from New England. This was taken at Needham, Mass., Aug. 23, 1908, in an abandoned field on sandy loam. The species is common in the West.

Subfamily Acrydiinæ, Pygmy Locusts (Tettiginæ, Grouse Locusts).

All the Pygmy Locusts hibernate in the adult stage. They rest on the bare earth instead of perching on vegetation.

124. Crested Pygmy Locust, Nomotettix cristatus cristatus Scudder.

Found everywhere on light soils, such as dry pastures and mowing-lands, probably throughout New England; abundant locally. Adults occur throughout the year but are most plentiful in April, May, and October.

125. Angulate Pygmy Locust, Acrydium granulatum granulatum Kirby.

Common throughout New England on the moist earth of meadows, especially on sandy soil, and the margins of swamps and streams. Adults are most numerous in April, May, August, and September.

125a. Broad-shouldered Angulate Pygmy Locust, Acrydium granlatum incurvatum Hancock.

A form described from the West, four examples of which have been taken at Moosehead Lake and in the alpine zone of the White Mt. region.

126. Ornate Pygmy Locust, Acrydium ornatum ornatum Say.

Lives in wet meadows and damp spots on upland soils through- 
out New England. Generally distributed, sometimes very common locally. Most numerous in spring and fall months.

127. Hancock's Pygmy Locust, Acrydium hancocki Morse.

Known from Randolph, N. H., and northern Maine, in July and August. Taken on damp spots on roadsides and in fields.

128. Obscure Pygmy Locust, Acrydium arenosum angustum Hancock.

Widely distributed and common locally from eastern Maine and northern Vermont southward. Found in the same haunts as the Ornate Pygmy Locust.

129. Hooded Pygmy Locust, Paratettix cucullatus Burmeister.

Common, even abundant locally, in Connecticut in late August. Lives as far north as Alstead, N. H., in the Connecticut valley, and is recorded by Scudder from the vicinity of Boston. It frequents the shores of ponds and streams, resting on sand, mud, or stones.

130. Sedge Pygmy Locust, Tettigidea lateralis parvipennis Harris.

Wet, sedgy meadows, springy runs, etc., throughout New England, in every month of the season. Common, sometimes plentiful, especially on sandy loam.

\section{NOTES ON SOUTH AFRICAN PHORIDA (DIPTERA).}

By Charles T. Brues,

Bussey Institution, Harvard University.

Dr. L. Peringuey of the South African Museum at Cape Town, recently sent me several specimens of Phoridæ belonging to the Museum collections, one of which is of considerable interest. ${ }^{1}$ This is the female of the genus Conoprosopa which proves to be almost completely wingless and very highly modified. There is also a very distinct species of Paraspiniphora which is here described.

\footnotetext{
1 Owing to the conditions brought about by the war and the impossibility of publishing the Annals of the South African Museum at the present time, Dr. Peringuey has kindly given me permission to have this short note published in an American journal.
} 

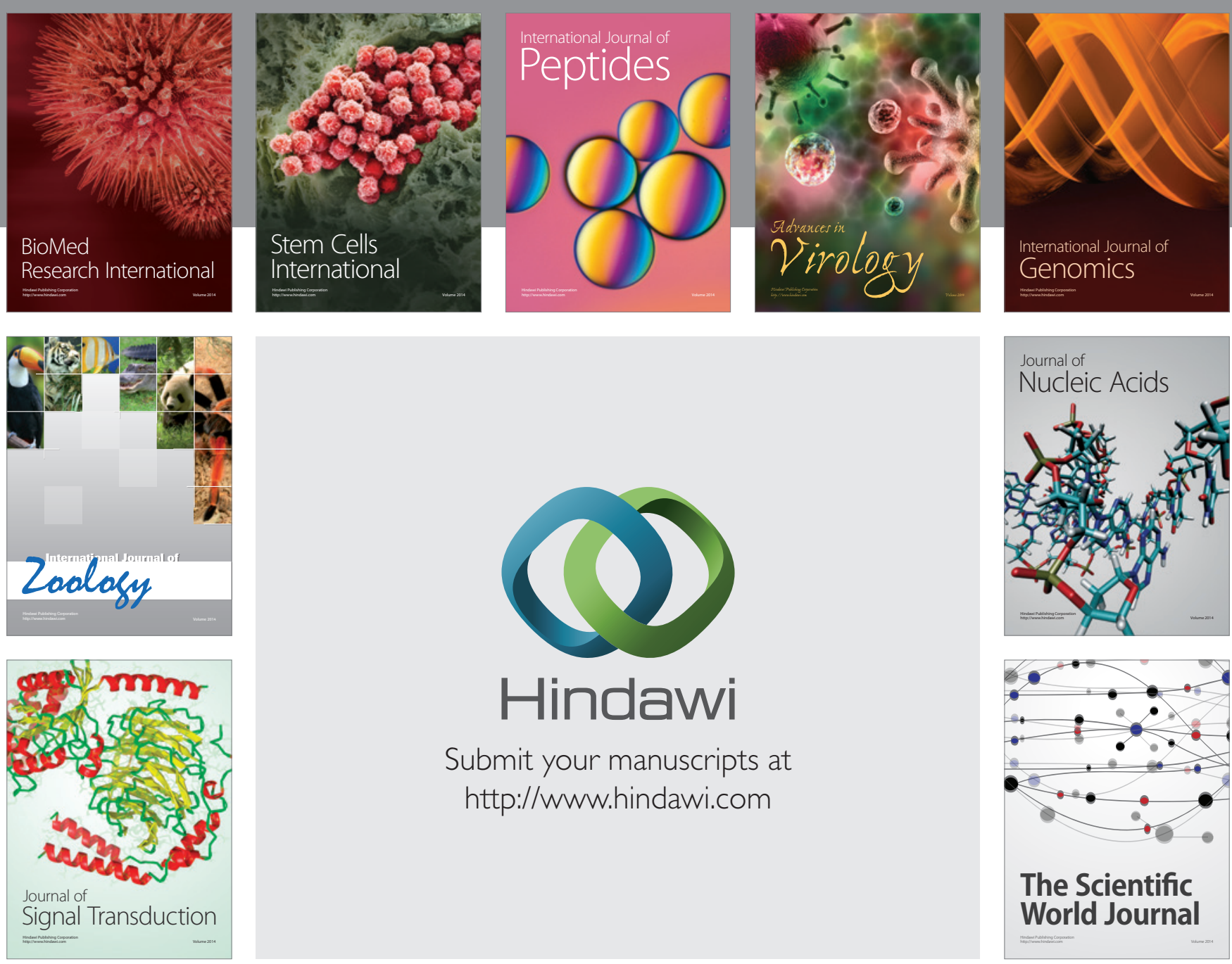

Submit your manuscripts at

http://www.hindawi.com
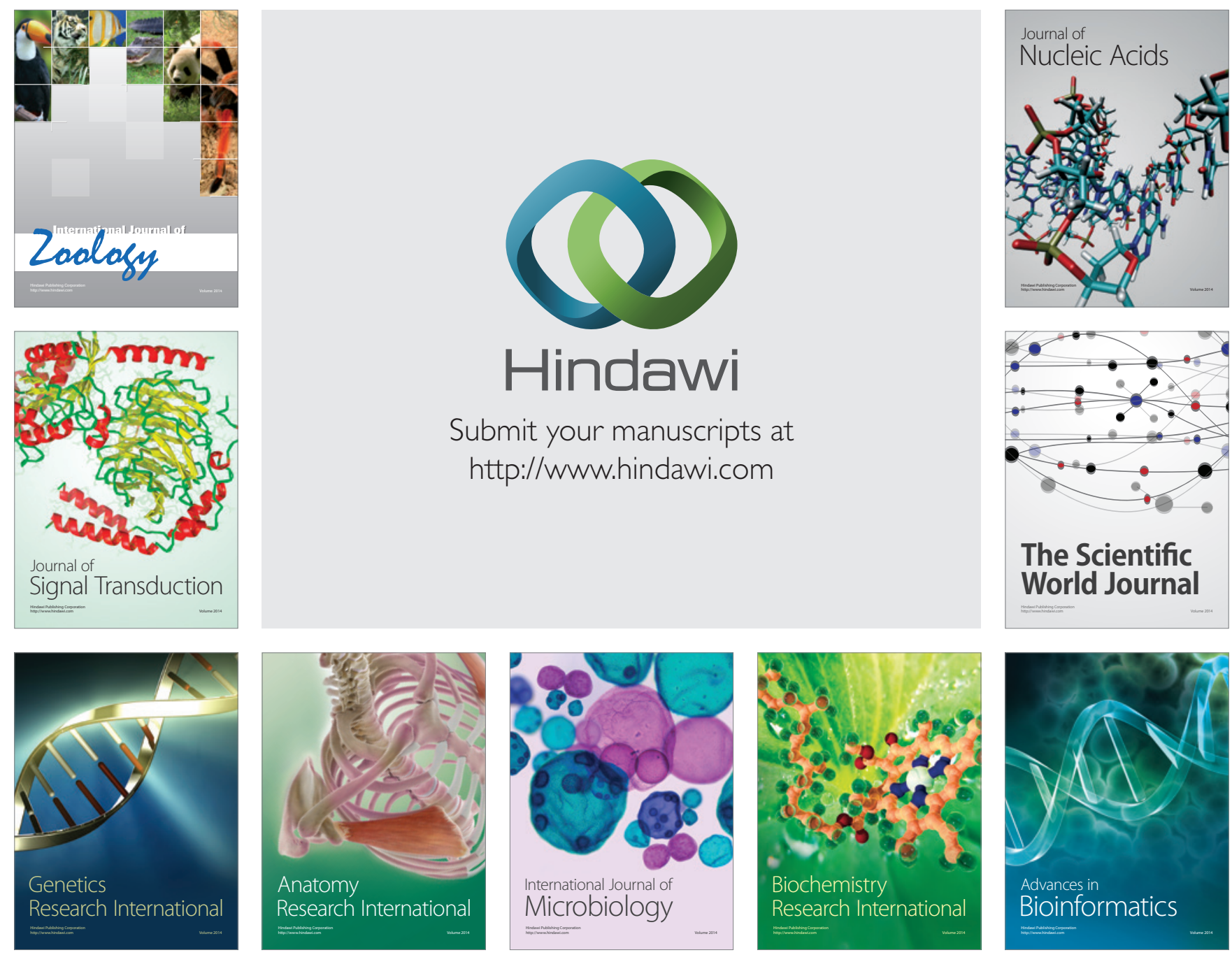

The Scientific World Journal
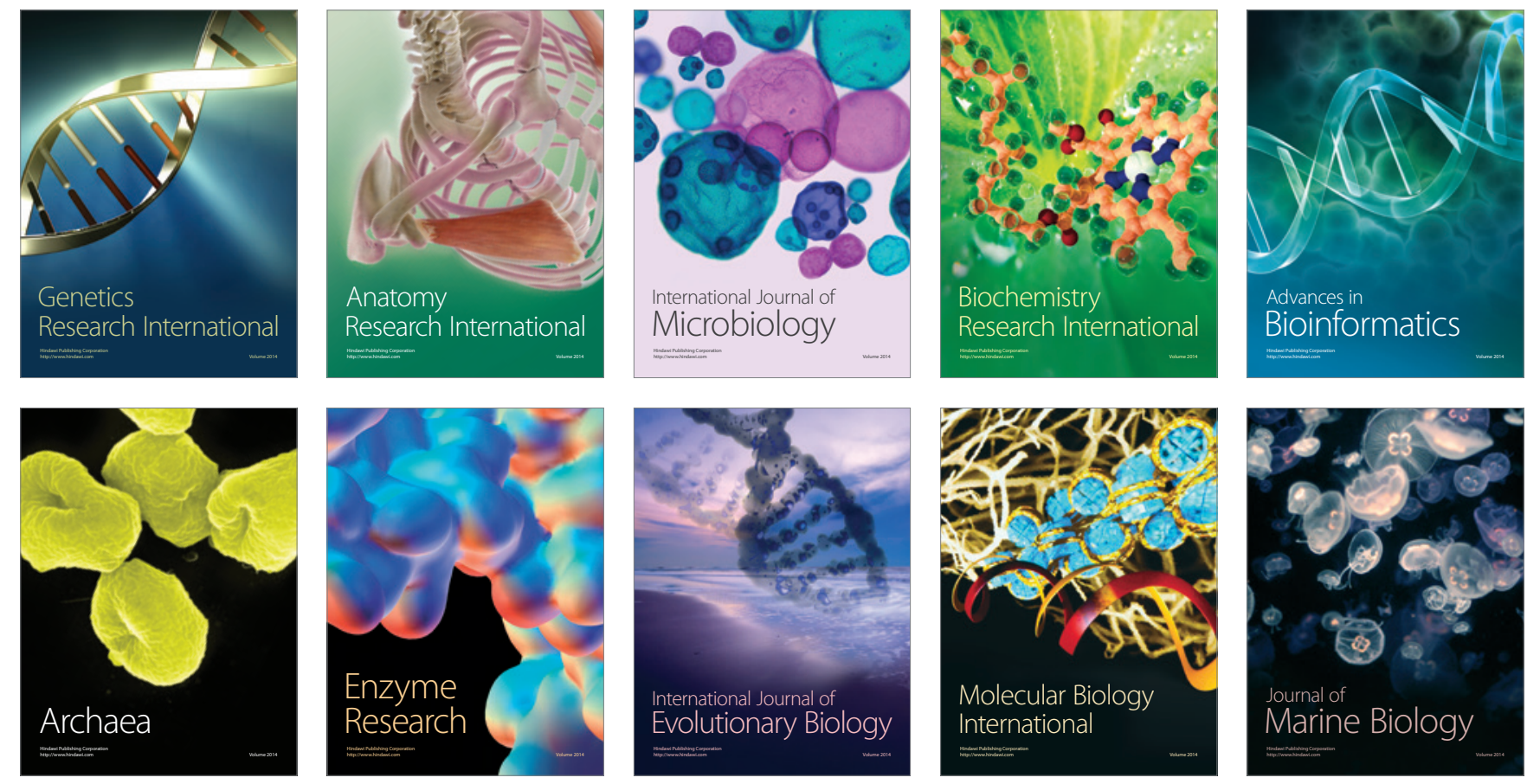